\title{
EFEK INTERVENING STRUKTUR MODAL PADA PENGARUH UKURAN PERUSAHAAN TERHADAP PROFITABILITAS
}

\author{
I Made Purba Astakoni $^{1 *}$ dan Ni Putu Nursiani ${ }^{2}$ \\ 1. Dosen Tetap pada STIMI Handayani Denpasar, \\ 2. Dosen Tetap Prog Studi Manajemen \& Bisnis Fak Ekonomi Undana-Kupang NTT \\ *Email; astakonimade@gmail.com
}

DiPublikasi: 01/01/2020

http://dx.doi.org/10.22225/kr.11.2.1422.137-147

\begin{abstract}
The objectives of this study are (1). (2) Analyzing the influence of firm size on profitability, (3) Analyzing the effect of capital structure on profitability, (4) Analyzing the role of capital structure variables in influencing the influence of firm size on profitability. The population in this study were all manufacturing companies in the Cosmetics and Household Purposes Sector listed on the Indonesia Stock Exchange (IDX). The total population in this study is 6 manufacturing companies in the cosmetics sector and household needs. Based on predetermined criteria, the number of samples is 3 companies, so the data analyzed is panel data with a total of 18 observations. Data analysis techniques use the Partial Least Square (PLS) approach. PLS is a model of Structural Equation Modeling (SEM) based on components or variants. PLS is a powerful analytical method because it is not based on many assumptions. The results of analysis and hypothesis testing indicate; The first hypothesis states that there is a significant positive effect on firm size on capital structure. The results of the analysis found that the size of the company had no significant positive effect on the capital structure so that the first hypothesis was not acceptable. The second hypothesis states that there is a significant positive effect on firm size on profitability. The results of the analysis found that the size of the company had no significant positive effect on profitability so that the second hypothesis was not acceptable. The third hypothesis which states there is a significant positive effect of capital structure on profitability. The results of the analysis found that the capital structure had a significant positive effect on profitability so that the third hypothesis could be accepted. In testing with the Sobel test it was found that the capital structure has not been tested as an intervening variable on the effect of firm size on profitability in the Cosmetics and Household Utilities manufacturing companies listed on the Indonesia Stock Exchange (IDX).
\end{abstract}

Keywords: Company size; capital structure; profitability

\begin{abstract}
Abstrak
Tujuan dari penelitian ini adalah (1). Menganalisis pengaruh ukuran perusahaan terhadap struktur modal, (2)Menganalisis pengaruh ukuran perusahaan terhadap profitabilitas, (3) Menganalisis pengaruh struktur modal terhadap profitabilitas,(4) Menganalisis peran variabel struktur modal dalam mengintervening pengaruh ukuran perusahaan terhadap profitabilitas. Populasi dalam penelitian ini adalah seluruh perusahaan manufaktur Sektor Kosmetik dan Keperluan Rumah Tangga yang terdaftar di Bursa Efek Indonesia (BEI). Adapun jumlah populasi dalam penelitian ini sebanyak 6 perusahaan manufaktur sektor kosmetik dan keperluan rumah tangga. Berdasarkan kriteria yang telah ditetapkan maka jumlah sampel sebanyak 3 perusahaan, sehingga data yang dianalisis merupakan data panel dengan jumlah observasi sebanyak 18. Teknik analisis data menggunakan pendekatan Partial Least Square (PLS). PLS adalah model persamaan Structural Equation Modeling (SEM) yang berbasis komponen atau varian. PLS merupakan metode analisis yang powerfull karena tidak didasarkan pada banyak asumsi.Hasil analisis dan pengujian hipotesis menunjukkan; Hipotesis pertama yang menyatakan terdapat pengaruh signifikan positif ukuran perusahaan terhadap struktur modal. Hasil analisis menemukan ukuran perusahaan berpengaruh tidak signifikan positif terhadap struktur modal sehingga hipotesis pertama tidak dapat diterima. Hipotesis kedua yang menyatakan terdapat pengaruh signifikan positif ukuran perusahaan terhadap profitabilitas. Hasil analisis menemukan ukuran perusahaan berpengaruh tidak signifikan positif terhadap profitabilitas sehingga hipotesis kedua tidak dapat diterima. Hipotesis ketiga yang menyatakan terdapat pengaruh signifikan positif struktur modal terhadap profitabilitas. Hasil analisis menemukan struktur modal berpengaruh signifikan positif terhadap profitabilitas sehingga hipotesis ketiga dapat diterima. Pada pengujian dengan uji Sobel didapat bahwa struktur modal belum teruji sebagai sebagai variabel intervening pada pengaruh ukuran perusahaan terhadap profitabilitas pada perusahaan manufaktur Sektor Kosmetik dan Keperluan Rumah Tangga yang terdaftar di Bursa Efek Indonesia (BEI).
\end{abstract}

Kata Kunci: Ukuran perusahaan; struktur modal; profitabilitas

\section{PENDAHULUAN}

Kelangsungan hidup perusahaan (going concern) dipengaruhi oleh banyak hal antara lain 
aspek keuangan yang mencerminkan keberhasilan perusahaan dalam kinerjanya. Hal ini dikarenakan para pengguna informasi biasanya melihat keberhasilan suatu perusahaan dari kondisi keuangan dan kinerja keuangan yang dimiliki perusahaan. Salah satu cara untuk mengetahui kinerja keuangan yang sehat adalah dengan melihat bagaimana kemampuan perusahaan dalam memperoleh profit melalui rasio profitabilitas. Sebagaimana Horne \& John M (2012) menyatakan bahwa rasio profitabilitas merupakan pengukuran efisiensi operasi perusahaan.Profitabilitas menunjukkan kemampuan perusahaan dalam memperoleh laba,dimana perusahaan yang memiliki profitabilitas tinggi tiap tahunnya cenderung diminati oleh investor. Para investor ini menganggap perusahaan yang profitnya besar akan menghasilkan return yang besar pula. Perusahaan yang memiliki tingkat profitabilitas tinggi tiap tahunnya memiliki kecenderungan untuk menggunakan modal sendiri dibanding dengan menggunakan hutang. Hal ini sesuai yang dikatakan oleh (Brigham \& Houston 2011) bahwa "tingkat pengembalian yang tinggi memungkinkan perusahaan-perusahaan tersebut melakukan sebagian besar pendanaannya melalui dana yang dihasilkan secara internal". Perusahaan yang memiliki tingkat profitabilitas yang tinggi setiap tahunnya, memiliki kecenderungan untuk menggunakan modal sendiri dibandingkan dengan menggunakan hutang (Kusuma dan Arifin 2012). Asumsi lain juga menyebutkan dengan Return On Assets yang tinggi, yang berarti bahwa laba bersih yang dimiliki perusahaan tinggi,oleh karena itu apabila perusahaan menggunakan hutang yang besar, tidak akan berpengaruh terhadap struktur modal, karena kemampuan perusahaan dalam membayar bunga juga tetap tinggi.

Didalam meningkatkan kinerja keuangan perusahaan, pihak manajemen perlu mengkombinasikan antara modal yang berasal dari internal perusahaan dan eksternal perusahaan yang disebut juga dengan struktur modal. Kombinasi yang tepat dalam pemilihan modal, akan mampu menghasilkan struktur modal yang optimal, sehingga mampu menjadi pondasi kuat bagi perusahaan untuk menjalankan aktivitas produksinya, serta mampu mendatangkan keuntungan dan profitabilitas bagi perusahaan.Struktur modal terkait erat dengan struktur keuangan. Menurut (Brigham \& Houston, 2011) "Struktur keuangan adalah cara bagaimana perusahaan membiayai aktivanya. Struktur keuangan dapat dilihat pada sisi kanan neraca yang terdiri dari hutang jangka pendek, hutang jangka panjang dan modal pemegang saham. Jadi, struktur modal suatu perusahaan hanya merupakan sebagian dari struktur keuangannya". Struktur modal merupakan masalah yang penting bagi perusahaan karena baik buruknya struktur modal akan mempunyai efek langsung terhadap posisi finansial perusahaan, yang pada akhirnya akan mempengaruhi profitabilitas perusahaan. Kesalahan dalam menentukan struktur modal akan berdampak luas terutama apabila perusahaan terlalu besar dalam menggunakan hutang, sehingga beban tetap yang harus ditanggung perusahaan semakin besar pula. Hal ini juga berarti akan meningkatkan risiko finansial, yaitu risiko saat perusahaan tidak dapat membayar beban bunga atau angsuran hutangnya. Struktur modal yang optimal dapat meminimumkan biaya modal rata-rata (average cost of capital) dan memaksimumkan nilai perusahaan. Oleh karena itu, agar kondisi tersebut dapat tercapai, maka perlu dipertimbangkan variabel-variabel yang mempengaruhi struktur modal. Sartono (2010) menyatakan para manajer keuangan perlu mempertimbangkan beberapa faktor penting antara lain tingkat penjualan, struktur asset, tingkat pertumbuhan perusahaan, profitabilitas, variabel laba, perlindungan pajak, skala perusahaan, kondisi intern perusahaan dan ekonomi makro.

Ukuran secara umum dapat diartikan sebagai suatu perbandingan besar atau kecilnya suatu objek. Ukuran perusahaan adalah suatu skala dimana dapat diklasifikasikan besar kecilnya perusahaan, sehingga dapat disimpulkan bahwa ukuran perusahaan merupakan cerminan total asset yang dimiliki perusahaan. Semakin besar ukuran perusahaan akan mempengaruhi keputusan manajemen dalam memutuskan pendanaan apa yang akan digunakan agar keputusan pendanaan dapat mengoptimalkan nilai perusahaan. Menurut (Riyanto, 2010), suatu perusahaan yang besar dimana sahamnya tersebar sangat luas, setiap perluasan modal saham hanya akan mempunyai pengaruh yang kecil terhadap kemungkinan hilangnya atau tergesernya kontrol dari pihak dominan terhadap perusahaan yang bersangkutan. Sebaliknya perusahaan yang kecil dimana sahamnya hanya tersebar di lingkungan kecil, penambahan jumlah saham akan mempunyai pengaruh yang besar terhadap 
kemungkinan hilangnya kontrol pihak dominan terhadap perusahaan yang bersangkutan. Ukuran perusahaan (Firm Size) merupakan salah satu faktor yang dipertimbangkan perusahaan dalam menentukan berapa besar kebijakan keputusan pendanaan (struktur modal) dalam memenuhi ukuran atau besarnya aset perusahaan. Menurut (Moeldjadi, 2006) "suatu perusahaan yang berukuran besar lebih mudah memperoleh pinjaman jika dibandingkan dengan perusahaan kecil", akan tetapi, perusahaan besar seringkali mampu membiayai kegiatan operasional mereka sendiri dengan sumber internal daripada sumber eksternal, dikarenakan perusahaan besar memiliki pendapatan yang besar dibandingkan dengan perusahaan kecil, sehingga tidak perlu bergantung pada sumber pendanaan eksternal. Perusahaan besar lebih mudah memperoleh pinjaman, sehingga mereka akan cenderung untuk berhutang karena kemungkinan mengalami risiko kebangkrutan yang rendah, disamping itu perusahaan besar dimana sahamnya tersebar sangat luas akan lebih berani mengeluarkan saham baru dalam memenuhi kebutuhannya untuk membiayai pertumbuhan penjualan dibandingkan dengan perusahaan yang kecil" (Riyanto, 2010). Pada sisi yang lain bahkan (Seftianne \& Ratih, 2011) menjelaskan perusahaan yang besar memiliki kecenderungan untuk menggunakan sumber pendanaan eksternal dari pada perusahaan kecil karena accessibility perusahaan ke pasar modal. Semakin besar ukuran perusahaan maka struktur modal akan semakin tinggi. Semakin kecil ukuran perusahaan maka semakin kecil pula struktur modalnya.

Beberapa penelitian yang menunjukan research gap antara lain: penelitian (Astohar, 2017) yang menyatakan bahwa ukuran perusahaan berpengaruh positif dan tidak signifikan terhadap struktur modal. Sementara hasil penelitian (Swaputra, Astakoni, Ratini, \& Harwathy, 2018), (Nadzirah, Yudiaatmaja, \& Cipta, 2016), (Umam \& Mahfud, 2016) yang menyatakan bahwa ukuran perusahaan berpengaruh signifikan positif terhadap struktur modal. Hasil studi Umam \& Mahfud, (2016) yang menyatakan bahwa ukuran perusahaan berpengaruh tidak signifikan positif terhadap profitabilitas (ROA). Sementara studi yang dilakukan (Barus \& Leliani, 2013) (Sunarto \& Budi, 2009) yang menyatakan bahwa ukuran perusahaan berpengaruh signifikan positif terhadap profitabilitas. juga Swaputra et al, (2018) yang menyatakan bahwa ukuran perusahaan berpengaruh negatif dan signifikan terhadap profitabilitas.Penelitian (Utomo, 2015) dan (Astuti, Retnowati, \& Rosyid 2015) yang menyatakan bahwa struktur modal berpengaruh positif dan tidak signifikan terhadap profitabilitas. Berbeda dengan penelitian yang dilakukan oleh Swaputra et al, (2018) menyatakan bahwa struktur modal perusahaan berpengaruh negatif dan signifikan terhadap profitabilitas.

Berdasarkan paparan teori dan hasil riset sebelumnya, penelitian ini dilakukan untuk menguji kembali variabel-variabel yang mempengaruhi profitabilitas. Apakah hasil dari penelitian ini sejalan dengan penelitian-penelitian terdahulu atau menemukan hasil yang berbeda. Berdasarkan uraian diatas, maka yang menjadi pokok masalah adalah: (1) Apakah ukuran perusahaan berpengaruh terhadap struktur modal pada Sektor Kosmetik dan Keperluan Rumah Tangga yang terdaftar di Bursa Efek Indonesia; (2)Apakah ukuran perusahaan berpengaruh terhadap profitabilitas pada Sektor Kosmetik dan Keperluan Rumah Tangga yang terdaftar di Bursa Efek Indonesia;(3) Apakah struktur modal berpengaruh terhadap profitabilitas pada Sektor Kosmetik dan Keperluan Rumah Tangga yang terdaftar di Bursa Efek Indonesia;(4) Apakah struktur modal mampu sebagai variabel intervening dalam hubungan antara ukuran perusahaan dengan profitabilitas pada Sektor Kosmetik dan Keperluan Rumah Tangga yang terdaftar di Bursa Efek Indonesia. Atas dasar pokok permasalahan maka yang menjadi tujuan dari penelitian ini yaitu (1). Menganalisis pengaruh ukuran perusahaan terhadap struktur modal, (2)Menganalisis pengaruh ukuran perusahaan terhadap profitabilitas, (3) Menganalisis pengaruh struktur modal terhadap profitabilitas,(4)Menganalisis peran variabel struktur modal dalam mengintervening pengaruh ukuran perusahaan terhadap profitabilitas.

\section{TINJAUAN PUSTAKA DAN HIPOTESIS}

\section{Agency Theory}

Menurut (Rahayu, 2005) bahwa teori agensi memberi penjelasan yang sering digunakan dalam melihat variasi kebijakan hutang (struktur modal) pada berbagai perusahaan. Hubungan keagenan merupakan suatu kontrak antara prinsipal dengan agen. Teori Keagenan yang dikemukakan oleh Jensen dan Meckling (1976) dalam (Intan \& Widyawati 2016) menyatakan bahwa perusahaan 
memisahkan fungsi pengelolaan dan fungsi kepemilikan karena akan rentan terhadap konflik keagenan. Penyebab konflik antara manajer dengan pemegang saham di antaranya adalah keputusan yang berkaitan dengan aktivitas pencarian dana (financing decision) dan pembuatan keputusan yang berkaitan dengan bagaimana dana yang diperoleh tersebut diinvestasikan. Penggunaan instrumen hutang dan ekuitas akan menimbulkan biaya keagenan. Biaya ini adalah biaya yang dikeluarkan oleh prinsipal untuk mengawasi kinerja agen.

\section{Pecking Order Theory}

Teori ini dikemukakan oleh Donaldson tahun 1961, sedangkan penamaan pecking ordertheory ini dilakukan oleh Myers (1984) dalam (Chen \& Chen, 2011). Pecking order theory menjelaskan mengenai hierarki pendanaan, yaitu urut-urutan dana yang dapat digunakan sebagai preferensi pemenuhan kebutuhan dana oleh suatu perusahaan. Teori ini menyatakan bahwa perusahaan menyukai internal financing (pendanaan dari hasil operasi perusahaan berwujud laba ditahan), karena dana internal memungkinkan perusahaan untuk tidak perlu "membuka diri lagi" dari sorotan pemodal luar. Apabila pendanaan dari luar (external financing) diperlukan, maka perusahaan akan menerbitkan sekuritas yang paling aman terlebih dulu, yaitu dimulai melalui hutang, kemudian diikuti dengan sekuritas yang berkarakteristik opsi (seperti obligasi konversi), baru akhirnya apabila masih belum mencukupi, saham baru diterbitkan. Dalam Pecking Order Theory (Husnan \& Pudjiastuti, 2010) perusahaan yang profitabilitasnya tinggi akan menggunakan dana pinjaman yang sedikit,karena kebutuhan dana sudah tercukupi dari menggunakan sumber dana internal yaitu laba ditahan. Sedangkan perusahaan kurang profitabel akan menggunakan hutang lebih besar.

\section{Signalling Theory}

Sesuai pendapat (Brigham \& Houston 2011) mejelaskan bahwa teori sinyal adalah suatu tindakan yang diambil manajemen perusahaan yang memberi petunjuk bagi investor tentang bagaimana manajemen memandang prospek perusahaan. Perusahaan dengan prospek yang menguntungkan akan mencoba menghindari penjualan saham dan mengusahakan setiap modal baru yang diperlukan dengan cara-cara lain termasuk penggunaan hutang yang melebihi target struktur modal yang normal. Perusahaan dengan prospek yang kurang menguntungkan cenderung untuk menjual sahamnya. Pengumuman emisi saham oleh suatu perusahaan umumnya merupakan suatu isyarat (signal) bahwa manajemen memandang prospek perusahaan tersebut suram

\section{Profitabilitas}

Profitabilitas mengambarkan kemampuan perusahaan dalam memperoleh laba. Profitabilitas adalah hasil akhir dari sejumlah kebijakan dan keputusan yang dilakukan oleh perusahaan (Brigham \& Houston 2011). Perusahaan yang memiliki tingkat profitabilitas yang tinggi setiap tahunnya, memiliki kecenderungan untuk menggunakan modal sendiri dibandingkan dengan menggunakan hutang (Kusuma dan Arifin 2012). Asumsi lain juga menyebutkan dengan return on assets yang tinggi, yang berarti bahwa laba bersih yang dimiliki perusahaan tinggi. Oleh karena itu, apabila perusahaan menggunakan hutang yang besar, tidak akan berpengaruh terhadap struktur modal, karena kemampuan perusahaan dalam membayar bunga juga tetap tinggi. Menurut (Brigham, EF., 2006) ukuran yang bisa mewakili profitabilitas diantaranya Return on Asset (ROA), Return on Equity (ROE),Net Profit Margin (NPM) on Sales dan Basic Earning Power (BEP). Pendapat lain menyatakan ROA merupakan rasio pengukuran yang menggambarkan seberapa besar pendapatan yang dihasilkan perusahaan dalam setiap rupiah yang ditanamkan dalam bentuk aset, ROE merupakan rasio pengukuran yang menunjukkan seberapa besar pendapatan yang diterima bagi pemegang saham terhadap investasi yang ditanamkan dan NPM merupakan rasio yang menunjukkan tinggi rendahnya kemampuan perusahaan untuk menghasilkan laba bersih terhadap penjualannya (Syamsuddin, 2016)

\section{Struktur Modal}

Struktur modal merupakan perimbangan jumlah hutang jangka pendek yang bersifat permanen, hutang jangka panjang, saham preferen dan saham biasa (Sartono, 2010) . Struktur modal yang baik dan optimal adalah struktur modal yang dapat meminimumkan biaya dan menyeimbangkan risiko dengan tingkat pengembalian. Hal ini didukung oleh pendapat yang menyatakan bahwa "struktur modal yang dapat memaksimumkan nilai perusahaan atau harga saham adalah struktur modal yang baik" (Husnan danPudjiastuti 2010). Kebijakan 
mengenai struktur modal melibatkan trade off antara risiko dan tingkat pengembalian. Penambahan utang akan memperbesar risiko perusahaan tetapi sekaligus juga memperbesar tingkat pengembalian yang diharapkan. Menurut (Brigham \& Houston 2011) struktur modal dapat diukur dengan berbagai cara yaitu: (1) Debt to Assets Ratio (DAR), (2) Debt to Equity Ratio (DER), (3) Long term Debt to Assets Ratio (LDAR), dan (4) Equity to Assets Ratio (EAR). Struktur modal dalam penelitian ini diukur dengan menggunakan indikator yaitu Debt to Asset Ratio (DAR). Sedangkan (Syamsuddin, 2016) menjelaskan Debt to Total Asset Ratio (DAR) digunakan untuk mengukur seberapa besar jumlah aktiva perusahaan dibiayai dengan total hutang.

\section{Ukuran Perusahaan}

Ukuran perusahaan dapat diartikan sebagai besar kecilnya perusahaan dilihat dari besarnya nilai equity, nilai perusahaan, ataupun hasil nilai total aktiva dari suatu perusahaan (Riyanto ,2010). Semakin besar ukuran perusahaan semakin mudah untuk mendapatkan modal eksternal dalam jumlah yang lebih besar, sehingga investor tertarik untuk menanamkan modalnya pada perusahaan tersebut sehingga menaikan profitabilitas dan nilai perusahaan. Beaver, Kettler dan Scholes (1970) dalam Sunarto dan Budi (2009) menyatakan bahwa semakin besar nilai yang dihasilkan suatu perusahaan, yang tercermin dari nilai aset yang dimilikinya, maka akan mempengaruhi prospek perusahaan di masa depan. Selain itu Short dan Keasey (1999) dalam Sunarto dan Budi 2009) menyatakan bahwa perusahaan berukuran skala besar akan semakin mampu mencapai skala ekonomisnya yang akhirnya akan meningkatkan keuntungan. (Seftianne \& Ratih 2011), menyatakan bahwa penentuan besar kecilnya skala perusahaan dapat ditentukan berdasarkan total penjualan, total aktiva, rata-rata tingkat penjualan dan rata-rata total aktiva.

\section{Pengaruh Ukuran Perusahaan Terhadap Struktur Modal}

Ukuran perusahaan (Firm Size) merupakan salah satu faktor yang dipertimbangkan perusahaan dalam menentukan berapa besar kebijakan keputusan pendanaan (struktur modal) perusahaan. Moeldjadi, (2006) berpendapat bahwa "suatu perusahaan yang berukuran besar lebih mudah memperoleh pinjaman jika dibandingkan dengan perusahaan kecil", akan tetapi, perusahaan besar seringkali mampu membiayai kegiatan operasional mereka sendiri dengan sumber internal daripada sumber eksternal, hal ini dikarenakan perusahaan besar memiliki pendapatan yang juga besar dibandingkan dengan perusahaan kecil, sehingga tidak perlu bergantung pada sumber pendanaan eksternal. Besar kecilnya perusahaan sangat tergantung pada struktur modal, terutama berkaitan dengan kemampuan memperoleh pinjaman. Perusahaan besar lebih mudah memperoleh pinjaman, sehingga mereka akan cenderung untuk berhutang karena kemungkinan mengalami risiko kebangkrutan yang rendah, disamping itu perusahaan yang besar dimana sahamnya tersebar sangat luas akan lebih berani mengeluarkan saham baru dalam memenuhi kebutuhannya untuk membiayai pertumbuhan penjualan dibandingkan dengan perusahaan yang kecil" (Riyanto, 2010) .Menurut (Seftianne \& Ratih, 2011) , menyatakan bahwa perusahaan yang besar juga memiliki kecenderungan untuk menggunakan sumber pendanaan eksternal dari pada perusahaan kecil karena accessibility perusahaan ke pasar modal. Oleh karena itu, dapat disimpulkan semakin tinggi ukuran perusahaan maka struktur modal akan semakin tinggi. Begitu pula sebaliknya semakin kecil ukuran perusahaan maka semakin kecil pula struktur modalnya, sehingga hipotesis yang diangkat adalah;

H1 : Ukuran perusahaan (Firm Size) berpengaruh signifikan positif terhadap struktur modal.

\section{Pengaruh Ukuran Perusahaan Terhadap Profitabilitas}

Beaver, Kettler dan Scholes (1970) dalam (Sunarto \& Budi, 2009) menyatakan bahwa semakin besar nilai yang dihasilkan suatu perusahaan, yang tercermin dari nilai aset yang dimilikinya, maka akan mempengaruhi prospek perusahaan di masa depan. Selain itu (Niresh \& Velnampy, 2014) menyatakan bahwa ukuran perusahaan merupakan faktor utama dalam menentukan profitabilitas dari suatu perusahaan hal ini sesuai dengan konsep skala ekonomi yang ditemukan dalam pandangan neoklasik tradisional. Hal ini menunjukkan bahwa bertentangan dengan perusahaan kecil, produk dapat diproduksi dengan biaya yang lebih rendah oleh perusahaan yang lebih besar. Sesuai dengan konsep ini diharapkan hubungan yang 
positif antara ukuran perusahaan dan profitabilitas perusahaan. Beberapa hasil riset mendukung teori yang ada didapat oleh (Rifai, Rina, \& Magdalena, 2015) yang menemukan ada pengaruh yang signifikan antara ukuran perusahaan terhadap profitabilitas secara parsial. Adanya pengaruh yang signifikan dan positif ini mengindikasikan bahwa semakin besar ukuran perusahaan dapat menjelaskan dan memprediksi peningkatan profitabilitas. Sunarto dan Budi (2009) dengan hasil penelitian menunjukkan bahwa ukuran perusahaan yang diwakili oleh besaran nilai penjualan berpengaruh positif dan signifikan terhadap profitabilitas perusahaan.Berdasarkan paparan sebelumnya maka dapat diangkat hipotesis ;

H2; Ukuran perusahaan berpengaruh positif signifikan terhadap profitabilitas.

\section{Pengaruh Struktur Modal Terhadap Profitabilitas}

Rasio leverage (utang) menekankan pada peran penting pendanaan utang bagi perusahaan dengan menunjukkan persentase aktiva perusahaan yang didukung oleh pendanaan utang. Berdasarkan Pecking Order Theory, semakin besar rasio ini, menunjukkan bahwa semakin besar biaya yang harus ditanggung perusahaan untuk memenuhi kewajiban yang dimilikinya,sehingga hal ini dapat menurunkan profitabilitas yang dimiliki oleh perusahaan .Menurut (Horne \& John M, 2012) semakin tinggi rasio debt to total asset, semakin besar risiko keuangannya,sehingga hal ini mengakibatkan terjadinya peningkatan risiko sebagai akibat kemungkinan terjadinya default karena perusahaan terlalu banyak melakukan pendanaan aktiva dari hutang. Adanya risiko gagal bayar, maka biaya yang harus dikeluarkan oleh perusahaan untuk mengatasi masalah ini semakin besar. Adanya peningkatan hutang akan mempengaruhi risiko dan keuntungan yang diperoleh perusahaan yang diakibatkan dari penggunaan hutang tersebut. Hal ini disebabkan penggunaan hutang mempunyai risiko yang tinggi yaitu biaya modal, dengan kata lain, Debt to Equity Ratio (DER) berpengaruh negatif terhadap profitabilitas. Hal ini didukung oleh hasil penelitian (Rifna, 2014) yang menunjukkan bahwa variabel struktur modal yang diukur dengan Debt to Equity Ratio (DER), Debt to Assets Ratio (DAR) memiliki hubungan negatif terhadap profitabilitas, juga hasil yang didapat oleh (Rosyadah, 2012) yang menyatakan bahwa Debt to Total Assets Ratio (DAR) berpengaruh terhadap Return on Equity (ROE). Dari uraian diatas, dapat ditarik hipotesis sebagai berikut, H3 : Capital Structure berpengaruh negatif dan signifikan terhadap profitabilitas

\section{III.METODE}

\section{Obyek dan Subyek Penelitian}

Objek penelitian atau variabel penelitian yaitu Ukuran Perusahaan yang diproksi dengan Ln Total Asset (LnTA), Struktur Modal yang diproksi dengan Debt to Asset Ratio (DAR) dan Profitabilitas diproksi dengan Return on Equity (ROE). Sedangkan subyek penelitian ini adalah Perusahaan Industri Manufaktur Sektor Kosmetik dan Keperluan Rumah Tangga yang terdaftar di BEI pada Tahun 2012-2017.

\section{Definisi Operasional Variabel}

\section{Variabel Eksogen}

Variabel eksogen dalam penelitian ini adalah: Ukuran Perusahaan (Size).Ukuran Perusahaan adalah besar kecilnya perusahaan dapat diukur dengan total aktiva/besar harta perusahaan dengan menggunakan perhitungan nilai logaritma total aktiva/ LnTA.

\section{Variabel Endogen}

\section{Struktur Modal}

Struktur modal diukur dengan Debt to Asset Ratio (DAR). Debt to Total Assets Ratio (DAR) digunakan untuk mengukur seberapa besar jumlah aktiva perusahaan dibiayai dengan total hutang. Semakin tinggi rasio ini berarti semakin besar jumlah modal pinjaman yang digunakan untuk investasi pada aktiva guna menghasilkan keuntungan bagi perusahaan (Syamsuddin, 2016)

Profitabilitas

Profitabilitas adalah kemampuan perusahaan dalam memperoleh laba. Profitabilitas diukur dengan Return On Equity (ROE). Return On Equity (ROE) adalah perbandingan antara jumlah laba yang tersedia bagi pemilik modal sendiri dengan jumlah modal sendiri yang menghasilkan laba tersebut (Riyanto, 2010)

\section{Populasi ,Sampel dan Metode Pengumpulan Data}

\section{Populasi}

Populasi adalah gabungan dari seluruh elemen yang terbentuk peristiwa, hal, atau orang yang 
memiliki karakteristik serupa yang menjadi pusat perhatian peneliti, karena dipandang sebagai semesta penelitian (Ferdinand, 2011) . Populasi dalam penelitian ini adalah seluruh perusahaan manufaktur Sektor Kosmetik dan Keperluan Rumah Tangga yang go public dan sahamnya terdaftar di Bursa Efek Indonesia (BEI). Adapun jumlah populasi dalam penelitian ini sebanyak 6 perusahaan manufaktur sektor kosmetik dan keperluan rumah tangga yang dijadikan populasi dalam penelitian ini (Tabel1 ) berikut:

Sampel

Tabel 1

Perusahaan Manufaktur Sektor Kosmetik dan Keperluan Rumah Tangga yang terdaftar di BEI Periode 2012-2017

\begin{tabular}{|c|c|c|}
\hline No & Kode Perusahaan & Nama Perusahaan \\
\hline 1 & ADES & $\begin{array}{l}\text { Akasha Wira International Tbk.PT } \\
\text { (d.h Ades Waters Indonesia Tbk.PT) }\end{array}$ \\
\hline 2 & KINO & Kino Indonesia Tbk \\
\hline 3 & MBTO & Martina Berto Tbk \\
\hline 4 & MRAT & Mustika Ratu Tbk \\
\hline 5 & TCID & Mandom Indonesia Tbk \\
\hline 6 & UNVR & Unilever Indonesia Tbk \\
\hline
\end{tabular}

Sumber : www.idx.co.id

Menurut (Sugiyono, 2007) mengatakan bahwa "Sampel adalah bagian dari jumlah dan karakteristik yang dimiliki oleh populasi tersebut." Pengambilan sampel merupakan suatu langkah untuk menentukan besarnya sampel yang diambil dalam melaksanakan suatu penelitian . Dalam penelitian ini adapun teknik sampling yang digunakan adalah purposive sampling atau pengambilan sampel berdasarkan kriteria-kriteria tertentu yaitu:

a).Perusahaan manufaktur Sektor Kosmetik dan Keperluan Rumah Tangga yang terdaftar di BEI periode 2012 -2017.

b).Laporan keuangan perusahaan menggunakan mata uang rupiah,
c).Tersedianya laporan keuangan tahunan dan dipublikasikan lengkap selama periode 2012 -2017 ,

d).Tersedianya data terkait yang lengkap sesuai dengan variabel yang akan diteliti selama periode 2012-2017.

Berdasarkan Kriteria yang telah ditetapkan tersebut, maka perusahaan sektor kosmetik dan keperluan rumah tangga yang terdaftar di Bursa Efek Indonesia yang dijadikan sampel dalam penelitian ini sesuai Tabel 2, sehingga data yang diolah merupakan data panel dengan jumlah observasi yang diangkat sebanyak $3 \times 6=18$ observasi.

Metode Pengumpulan Data

Tabel 2

Sampel Penelitian

\begin{tabular}{ccc}
\hline No & Kode Perusahaan & Nama Perusahaan \\
\hline 1 & TCID & Mandom Indonesia Tbk \\
2 & MBTO & Martina Berto Tbk \\
3 & UNVR & Unilever Indonesia Tbk \\
\hline
\end{tabular}

Sesuai dengan sumber data yaitu data primer, maka metode pengumpulan data dalam penelitian ini adalah dengan menggunakan teknik dokumentasi yang berdasarkan laporan keuangan periode Tahun 2012 - 2017 yang terdaftar di BEI.

\section{Teknik Analisis Data}

Analisis Statistik Deskriptif

Statistik deskriptif adalah statistik yang digunakan untuk menganalisis data dengan cara mendeskripsikan data yang didapat tanpa bermaksud membuat kesimpulan yang berlaku umum (Sugiyono , 2007). Pada analisis ini yaitu mendeskripsikan variabel yang terdapat dalam penelitian menggunakan bantuan program spss ver 22 .

\section{Analisis Statistik Inferensial}

Pada fenomena bisnis, sebuah variabel tergantung dapat dipengaruhi oleh beberapa variabel bebas, dan juga mampu mempengaruhi 
variabel tergantung secara sekaligus,sehingga mengakibatkan model penelitian menjadi sangat rumit (Suliyanto, 2011),(Ferdinand, 2014) .Dalam penelitian ini analisis data menggunakan pendekatan Partial Least Square (PLS). PLS adalah model persamaan Structural Equation Modeling (SEM) yang berbasis komponen atau varian. PLS merupakan metode analisis yang powerfull (Ghozali, 2011) karena tidak didasarkan pada banyak asumsi.Dalam PLS path modeling terdapat dua model yaitu outler model dan inner model.Perlu diketahui untuk analisis regresi berganda dengan variabel obseved dengan pendekatan PLS tidak perlu melakukan pengukuran model (measurement model), sehingga langsung dilakukan estimasi model struktural (Latan and Ghozali 2012,304), (Budhiasa 2016;36)

\section{Outler Model (Measurement Model)}

Terkait dengan indikator-indikator yang membentuk variabel laten dalam penelitian ini bersifat formatif, maka evaluasi model pengukuran (measurement model/outer model), dievaluasi dengan substantive contennya yaitu dengan membandingkan besarnya weight dan melihat signifikansi dari ukuran weight tersebut. Signifikansi weight indikator formatif diperoleh melalui prosedur boostrapping (Latan \& Ghozali, 2012)

\section{Inner Model (Structural Model).}

Evaluasi model struktural (Structural Model/ Inner Model) merupakan pengujian terhadap hipotesis penelitian. Apabila diperoleh nilai tstatistik lebih besar dari 1,96 dapat disimpulkan pengaruh antar variabel signifikan demikian sebaliknya.

\section{Pengujian Peran Variabel Intervening}

Dalam melihat peran intervening variabel struktur modal pada model yang diangkat dalam studi ini menggunakan Uji Sobel (Ferdinand, 2014).

\section{IV.HASIL DAN PEMBAHASAN}

\section{Hasil Penelitian}

\section{Analisis Statistik Deskriptif}

Pada variabel ukuran perusahaan (yang diproksi dengan LnTA) rata-rata (mean) sebesar 28,5930. Nilai tertinggi 30,5705 dan nilai terendah 27,1359. Pada variabel struktur modal (yang diproksi dengan DAR) rata-rata (mean) sebesar 0,4079. Nilai tertinggi 0,7264 dan nilai terendah 0,1306. Pada variabel profitabilitas (yang diproksi dengan ROE) rata-rata (mean) sebesar 0,4799 . Nilai tertinggi 1,3585 dan nilai terendah $-0,0598$

\section{Analisis Statistik Infrensial}

Dalam studi ini, oleh karena pendekatan indikator tunggal dan bersifat formatif maka hanya dilakukan uji inner model. Uji Inner Model dipergunakan untuk mengevaluasi hubungan antar konstruk laten seperti yang telah dihipotesiskan dalam penelitian. Berdasarkan hasil analisis dengan PLS, didapatkan hasil dari Inner Weight menunjukkan bahwa profitabilitas, dipengaruhi oleh ukuran perusahaan (Size) dan struktur modal, dan struktur modal dipengaruhi oleh ukuran perusahaan, yang kesemua ini akan djelaskan pada pengujian hipotesis berikut.

\section{Path Analysis dan Pengujian Hipotesis}

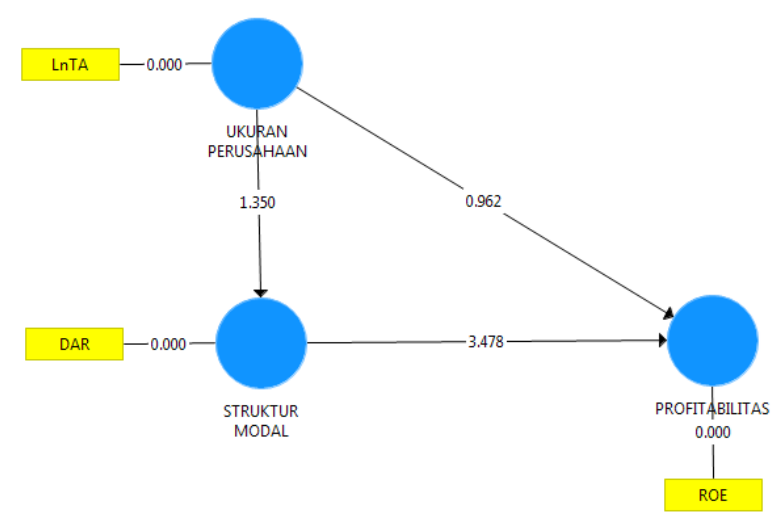

Gambar 1:

Hasil Pengujian Hipotesis 
Tabel 3 memberikan output estimasi untuk pengujian model struktural dimana hasil yang diharapkan adalah Ho ditolak atau nilai sig $<0,05$ (atau t-statistic $>1,96$ )

Berdasarkan formulasi uji sobel didapat nilai Z

Tabel 3

Path Analisis dan Pengujian Hipotesis

\begin{tabular}{|c|c|c|c|c|c|c|}
\hline Keterkaitan Antar Variabel & $\begin{array}{l}\text { Original } \\
\text { Sample } \\
\text { (O) }\end{array}$ & $\begin{array}{l}\text { Sample } \\
\text { Mean } \\
\text { (M) }\end{array}$ & $\begin{array}{l}\text { Standard } \\
\text { Error } \\
\text { (STERR) }\end{array}$ & $\begin{array}{l}\text { T Statistics } \\
\text { (O/STERR) }\end{array}$ & P-Value) & Ket \\
\hline $\begin{array}{l}\text { Ukuran Perusahaan -> } \\
\text { Profitabilitas }\end{array}$ & 0,166 & 0,238 & 0,195 & 0,962 & 0,394 & Tidak Sig \\
\hline $\begin{array}{l}\text { Ukuran Perusahaan -> Struktur } \\
\text { Modal }\end{array}$ & 0,262 & 0,344 & 0,212 & 1,350 & 0,218 & Tidak Sig \\
\hline Struktur Modal-> Profitabilitas & 0,688 & 0,615 & 0,206 & 3,478 & 0,001 & Sig \\
\hline
\end{tabular}

Sumber: Hasil olah data dengan PLS, 2019

Tabel 4

Path Analisis dan Uji Intervening

\begin{tabular}{ccc}
\hline Keterkaitan Antar Variabel & $\begin{array}{c}\text { Original Sample } \\
(\text { O) }\end{array}$ & $\begin{array}{c}\text { Standard Error } \\
\text { (STERR) }\end{array}$ \\
\hline Ukuran Perusahaan -> Struktur Modal & 0,262 & 0,187 \\
Struktur Modal -> Profitabilitas & 0,262 & 0,212 \\
\hline
\end{tabular}

(Sobel Test) dengan bantuan Statistics Calculators sebesar $Z=1,356(<1,98)$ dengan $p$ value $0,175(>0,05)$, sehingga struktur modal belum mampu mengintervening model yang diangkat dalam studi ini.

\section{Uji Hipotesis \& Pembahasan Hasil Penelitian Pengaruh Ukuran Perusahaan terhadap Struktur Modal}

Hipotesis pertama yang menyatakan terdapat pengaruh signifikan positif ukuran perusahaan terhadap struktur modal . Hasil analisis menemukan koefisien sebesar 0,262 (positif) dengan nilai t hitung $1,350(<1,96)$ atau nilai $\mathrm{p}$ value 0,218 (tidak signifikan). Ini berarti ukuran perusahaan berpengaruh tidak signifikan positif terhadap struktur modal sehingga hipotesis pertama tidak dapat diterima.Hasil penelitian ini sejalan dengan penelitian yang dilakukan oleh Astohar, (2017) yang menyatakan bahwa ukuran perusahaan berpengaruh positif dan tidak signifikan terhadap struktur modal (DER). Sementara hasil ini berbeda dengan penelitian yang dilakukan Ida Bagus Swaputra et al, (2018) dan Nadzirah, Yudiaatmaja, \& Cipta, (2016), Umam \& Mahfud, (2016) yang menyatakan bahwa ukuran perusahaan berpengaruh signifikan positif terhadap struktur modal. Hal ini sejalan dengan teori pecking order yang menyatakan bahwa, jika penggunaan dana internal tidak mencukupi, maka digunakan alternatif kedua yaitu menggunakan hutang. Jadi semakin besar ukuran suatu perusahaan, maka kecenderungan menggunakan modal asing juga semakin besar. Hal ini disebabkan karena perusahaan besar membutuhkan dana yang besar pula untuk menunjang operasionalnya,dan salah satu alternatif pemenuhannya adalah dengan modal asing apabila modal sendiri tidak mencukupi (Halim, 2007) . Perusahaan yang berukuran besar cenderung lebih fleksibel dalam mengakses sumber dana, sehingga akan meningkatkan hutangnya untuk memaksimalkan struktur modal.

\section{Pengaruh Ukuran Perusahaan terhadap Profitabilitas}

Hipotesis kedua yang menyatakan terdapat pengaruh signifikan positif Ukuran Perusahaan terhadap Profitabilitas . Hasil analisis menemukan koefisien sebesar 0,166 (positif) dengan nilai t hitung $0,962(<1,96)$ atau nilai $\mathrm{p}$ value 0,394 (tidak signifikan). Ini berarti ukuran perusahaan berpengaruh tidak signifikan positif terhadap profitabilitas sehingga hipotesis kedua tidak dapat diterima. Hasil studi ini sejalan dengan penelitian yang dilakukan oleh Umam \& Mahfud, (2016) yang menyatakan bahwa ukuran perusahaan berpengaruh tidak signifikan positif terhadap profitabilitas (ROA). Sementara studi ini tidak sejalan dengan hasil penelitian yang dilakukan Barus \& Leliani, (2013) dan Sunarto \& Budi, (2009) yang menyatakan bahwa ukuran perusahaan berpengaruh signifikan positif terhadap profitabilitas. juga dengan penelitian 
yang dilakukan oleh Swaputra et al, (2018) yang menyatakan bahwa ukuran perusahaan berpengaruh negatif dan signifikan terhadap profitabilitas. Hal ini sesuai dengan pandangan Beaver, Kettler dan Scholes (1970) dalam Sunarto \& Budi, (2009) yang menyatakan bahwa semakin besar nilai yang dihasilkan suatu perusahaan, yang tercermin dari nilai aset yang dimilikinya, maka akan mempengaruhi prospek perusahaan di masa depan. Selain itu Niresh \& Velnampy, (2014) menyatakan bahwa ukuran perusahaan merupakan faktor utama dalam menentukan profitabilitas dari suatu perusahaan sehingga hal ini sesuai dengan konsep skala ekonomi yang ditemukan dalam pandangan neoklasik tradisional. Tentu sebaliknya bertentangan dengan perusahaan kecil, dimana perusahaan besar produk dapat diproduksi dengan biaya yang lebih rendah oleh perusahaan yang lebih besar.

\section{Pengaruh Struktur Modal terhadap Profitabilitas}

Hipotesis ketiga yang menyatakan terdapat pengaruh signifikan positif Struktur Modal terhadap Profitabilitas .Hasil analisis menemukan koefisien sebesar 0,688 (positif) dengan nilai $t$ hitung 3,478 $(>1,96)$ atau nilai $p$-value 0,001 (signifikan). Ini berarti Struktur Modal berpengaruh signifikan positif terhadap Profitabilitas sehingga hipotesis ketiga tidak dapat diterima. Hasil penelitian ini didukung oleh penelitian yang dilakukan Utomo, (n.d.) dan Astuti et al, (2015) yang menyatakan bahwa struktur modal berpengaruh positif dan tidak signifikan terhadap profitabilitas. Berbeda dengan penelitian yang dilakukan oleh Swaputra et al, (2018) menyatakan bahwa struktur modal perusahaan berpengaruh negatif dan signifikan terhadap profitabilitas. Sementara hasil studi ini tidak sejalan dengan konsep Pecking Order Theory maupun paparan Horne \& John M, (2012), yang menyatakan semakin besar rasio ini, menunjukkan bahwa semakin besar biaya yang harus ditanggung perusahaan untuk memenuhi kewajiban yang dimilikinya,sehingga hal ini dapat menurunkan profitabilitas yang dimiliki oleh perusahaan Lebih jauh Horne \& John M, (2012) memaparkan semakin tinggi rasio debt to total asset, semakin besar risiko keuangannya,sehingga hal ini mengakibatkan terjadinya peningkatan risiko sebagai akibat kemungkinan terjadinya default karena perusahaan terlalu banyak melakukan pendanaan aktiva dari hutang.

\section{SIMPULAN}

Hipotesis pertama yang menyatakan terdapat pengaruh signifikan positif ukuran perusahaan terhadap struktur modal. Hasil analisis menemukan Ukuran Perusahaan berpengaruh positif dan tidak signifikan terhadap Struktur Modal sehingga hipotesis pertama tidak dapat diterima.

Hipotesis kedua yang menyatakan terdapat pengaruh signifikan positif Ukuran Perusahaan terhadap Profitabilitas. Hasil analisis menemukan Ukuran Perusahaan berpengaruh positif dan tidak signifikan terhadap Profitabilitas sehingga hipotesis kedua tidak dapat diterima. Hipotesis ketiga yang menyatakan terdapat pengaruh signifikan positif Struktur Modal terhadap Profitabilitas. Hasil analisis menemukan Struktur Modal berpengaruh positif dan signifikan terhadap Profitabilitas sehingga hipotesis ketiga dapat diterima. Peran Struktur Modal Sebagai VariabeASTl Intervening pada pengaruh Ukuran Perusahaan terhadap Profitabilitas belum teruji dalam studi ini.

\section{DAFTAR PUSTAKA}

Astohar. (2017). Pengaruh Ukuran Perusahaan Dan Profitabilitas Terhadap Nilai Perusahaan Dengan Struktur Modal Sebagai Variabel Intervening (Studi pada Perusahaan Automotive and Allied Products di Bursa Efek Indonesia periode tahun 2010 ?? 2015). Jurnal Ilmiah Among Makarti, 11(20), 17-36.

Astuti, K. D., Retnowati, W., \& Rosyid, A. (2015). Pengaruh Struktur Modal Terhadap Profitabilitas (Studi Pada Perusahaan Go Publik Yang Menjadi 100 Perusahaan Terbaik Versi Majalah Fortune Indonesia Periode Tahun 2010-2012). Jurnal A kuntansi, 2(1), 49-60.

Barus, A. C., \& Leliani. (2013). Analisis Faktor-faktor Yang Mempengaruhi Profitabilitas Pada Perusahaan Manufaktur Di Bursa Efek Indonesia. Jurnal Wira Ekonomi Mikroskil, 3(02), 111-120.

Brigham, EF., and J. H. (2006). Dasar-Dasar Manajemen Keuangan (Edisi X). Jakarta: Salemba Empat.

Brigham, E. F., \& Houston, J. F. (2011). Dasar-dasar Manajemen. Keuangan. Jakarta: Salemba Empat.

Brigham, F. ., \& Houston, J. F. (2011). Essential of Financial Management ((2nd editi). United states of America.: Cengage Learning.

Budhiasa, S. (2016). Analisis Statistik Multivariate Dengan Aplikasi SEM PLS SmartPLS 3.2.6. (J. Atmaja, Ed.) (Edisi Pert). Denpasar: Udayana University Press.

Chen, S., \& Chen, L. (2011). Capital structure determinants : An empirical study in Taiwan, 5(27), 10974-10983. https://doi.org/10.5897/AJBM10.1334

Ferdinand, A. (2011). Metode Penelitian Manajemen Pedoman Penelitian Untuk Penulisan Skripsi,Tesis da Desertasi Ilmu Manajemen (3rd ed.). Semarang.

Ferdinand, A. (2014). Structural Equation Modeling Dalam Penelitian Manajemen Aplikasi Model-Model Rumit 
Dalam Penelitian Untuk Skripsi,Tesis dan Desertasi Doktor (5th ed.). Semarang: BP Undip Press.

Ghozali, I. (2011). Aplikasi Analisis Multivariate Dengan Program SPSS 19. (P. P.Harto, Ed.) (V). Semarang: Badan Penerbi Univ Diponogoro.

Halim, A. (2007). Manajemen Keuangan Bisnis. Bogor: Ghalia Indonesia.

Horne, J. C. V., \& John M, W. J. (2012). Prinsip Prinsip Manajemen Keuangan (Edisi Ke12). Jakarta: Salemba Empat.

Husnan, S., \& Pudjiastuti, E. (2010). Dasar- Dasar Manajemen Keuangan, Jilid I. Yogyakarta: UPP AMP YKPN.

Intan, L. fitria, \& Widyawati, D. (2016). Pengaruh Kepemilikan Saham , Kebijakan Dividen Tangibility, Size , Dan Profitabilitas Terhadap Struktur Modal. Jurnal Ilmu Dan Riset Akuntansi, 5 (4), 1-18

Kusuma, G. I. S., \& Arifin, Z. (2012). Analisis Pengaruh Profitabilitas (profitability) Dan Tingkat Pertumbuhan (Growth) Terhadap Struktur Modal dan Nilai Perusahaan (Studi pada Perusahaan Real Estate and Property yang Terdaftar di Bursa Efek Indonesia (BEI) Periode 2007-2011). Malang.

Latan, H., \& Ghozali, I. (2012). Partial Least Squares Konsep Teknik dan Aplikasi SmartPLS 2.0 Untuk Penelitian Empiris. (H. P. P, Ed.). Semarang: Badan Penerbit Univ Diponogoro.

Moeldjadi. (2006). Manajemen Keuangan: Pendekatan Kuantitatif dan Kualitatif. Jilid 1. Malang: Bayumedia Publishing.

Nadzirah, Yudiaatmaja, F., \& Cipta, W. (2016). Pengaruh ukuran perusahaan dan profitabilitas terhadap struktur modal. E-Journal Bisma, 4(1).

Niresh, J. A., \& Velnampy, T. (2014). Firm Size and Profitability: A Study of Listed Manufacturing Firms ed Manufacturing Firms in Sri Lanka. International Journal of Business and Management, 9(4), 57-64. https://doi.org/10.5539/ijbm.v9n4p57

Rahayu, D. S. (2005). Pengaruh Kepemilikan Saham Manajerial Dan Institusional Pada Struktur Modal Perusahaan. Jurnal A kuntansi Dan Auditing, 01(02), 181-197.

Rifai, M., Rina, A., \& Magdalena, M. (2015). Pengaruh Ukuran Perusahaan Struktur Modal dan Pertumbuhan Perusahaan Terhadap Profitabilitas Studi Pada Perusahaan Manufaktur Di BEI tahun 2010-2012. Semarang.

Rifna, N. (2014). Analisis Pengaruh Struktur Modal Terhadap Profitabilitas (Studi Pada Perusahaan Manufaktur Yang Terdaftar Di Bursa Efek Indonesia 2010-2012. Semarang.

Riyanto, B. (2010). Dasar Dasar Pembelanjaan Perusahaan. Yogyakarta: BPFE.

Rosyadah, F. (2012). Pengaruh Struktur Modal Terhadap Profitabilitas (Studi Pada Perusahaan Real Estate and Property Yang Terdaftar di Bursa Efek Indonesia (BEI) Periode 2009 - 2011). Malang.

Sartono, A. (2010). Manajemen Keuangan Teori dan Aplikasi. (A. A. Yulianto, Ed.) (Edisi 11). Yogyakarta: BPFE Yogyakarta.

Seftianne, \& Ratih, H. (2011). Faktor Faktor Yang Mempengaruhi Struktur Modal Pada Perusahaan
Publik Sektor Manufaktur. Jurnal Bisnis Dan

Akuntansi, Vol 13(No 1), Hal 39-56.

Sugiyono. (2007). Metode Penelitian Bisnis (Pendekatan Kuantitatif, Kualitatif dan R\&D) (2nd ed.). Bandung: Alfabeta.

Suliyanto. (2011). Ekonometrika Terapan Teori \& Apalikasi Dengan SPSS. (F. S. Suyantoro, Ed.) (Ed.I). Yogyakarta: CV.ANDI OFSET.

Sunarto, \& Budi, A. P. (2009). Pengaruh Leverage, Ukuran dan Pertumbuhan Perusahaan terhadap Profitabilitas. Jurnal TEMA, 6(1), 86-103. https://doi.org/ISSN: $1693-9727$

Swaputra, I. B., Astakoni, P. I. M., Ratini, M. P., \& Harwathy, S. T. I. (2018). Ukuran Perusahaan,Pertumbuhan, Dan Struktur Modal Sebagai Determinan Profitabilitas Perusahaan. Jurnal Riset Akuntansi Juara, 8(2), 24-36.

Syamsuddin, L. (2016). Manajemen Keuangan Perusahaan, Konsep Aplikasi Dalam Perencanaan Pengawasan Dan Pengambilan Keputusan (Edisi Baru). Jakarta: PT Raja Grafindo Persada.

Umam, M. C., \& Mahfud, M. K. (2016). Pengaruh Ukuran Perusahaan dan Likuiditas terhadap Struktur Modal dengan Profitabilitas sebagai Variabel Intervening (Studi pada Perusahaan Manufaktur yang Terdaftar di Bursa Efek Indonesia Periode 2010-2014). Diponegoro Journal of Management, 5(3), 23373792. https://doi.org/ISSN (Online): 2337-3792

Utomo, H. P. (2015). Pengaruh Struktur Modal Dan Pertumbuhan Perusahaan Terhadap Nilai Perusahaan Dengan Profitabilitas Sebagai Variabel Intervening (Studi Pada Perusahaan Properti Dan Real Estate Yang Listing Di BEI 2012-2015), Dokumen Karya Ilmiah $\mid$ Skripsi $\mid$ Prodi Manajeme. 